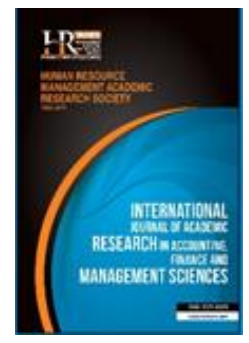

International Journal of Academic Research in Accounting, Finance and Management Sciences

Vol. 8, No.4, October 2018, pp. 101-109

E-ISSN: 2225-8329, P-ISSN: 2308-0337

(c) 2018 HRMARS

www.hrmars.com

To cite this article: Apriani, Y., Heryanto (2018). The Effect of Organizational Culture and Compensation on Employee Performance with Satisfaction as Intervening Variables in the Sub District Office of South Sipora Mentawai Islands Regency, International Journal of Academic Research in Accounting, Finance and Management Sciences 8 (4): 101-109.

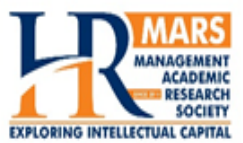

http://dx.doi.org/10.6007/IJARAFMS/v8-i4/5455 (DOI: 10.6007/IJARAFMS/v8-i4/5455)

\title{
The Effect of Organizational Culture and Compensation on Employee Performance with Satisfaction as Intervening Variables in the Sub District Office of South Sipora Mentawai Islands Regency
}

\author{
Yenni Apriani ${ }^{1}$, Heryanto ${ }^{2}$ \\ ${ }^{1}$ Institute of Economic Science, Finance, Banking and Development Padang, ${ }^{1}$ E-mail: yenni_apriani83@yahoo.com \\ ${ }^{2}$ School of Finance and Banking (STIE "KBP"), JL Khatib Sulaiman No. 61 Lolong Belanti, Padang Utara 25136, West \\ Sumatra, Indonesia, ${ }^{2}$ E-mail: dr_heryanto1@yahoo.com
}

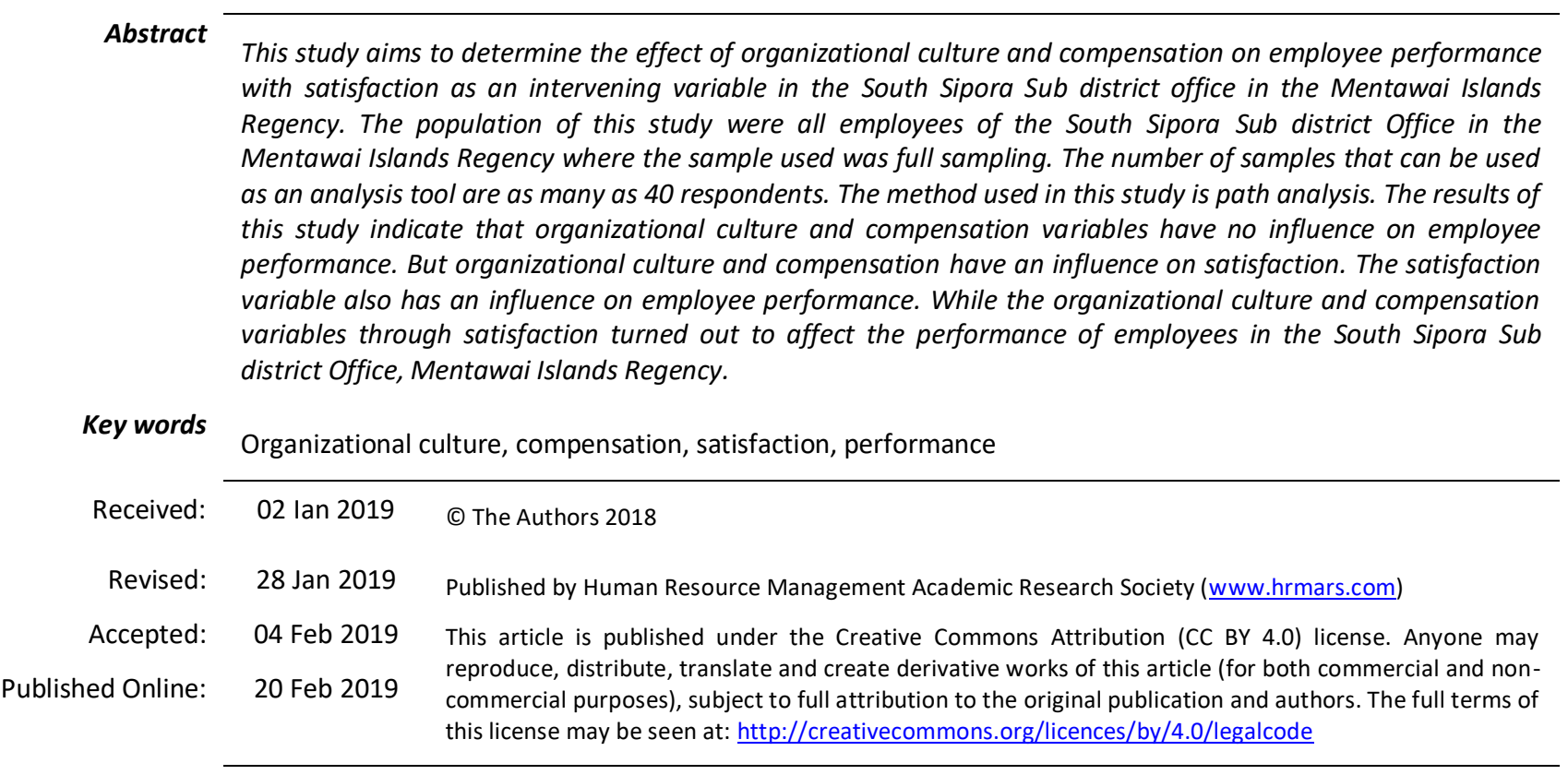

\section{Introduction}

Organizational culture is the norms and habits that apply in a company that affect the performance of employees of each organization. Compensation is an important aspect in relation to employees of a company. Employee performance is essentially a determining factor for developing an agency to develop effectively and efficiently. The South Sipora Sub district Office is one of the sub-districts of ten sub districts in the Mentawai Islands District. This sub-district is located on Sipora Island with an area of 268.47 Square kilometers (4.47\%) and Sioban is the capital of this sub-district. As the youngest district with Mentawai regency in 2000, the Mentawai Islands regency requires accelerated development. Of course this is also the duty and responsibility of the South Sipora Sub district government agency. As a population that is still developing, it requires good service and education to the community, so that people who are mostly educated in the lower middle class feel impressed and feel comfortable when dealing with this office.

As the importance of compensation in an employee's performance, the writer tries to make temporary observations of several employees from the reasons why the lack of attention of employees is at 
work. From the results of interviewing the author with several honer employees, the authors get the cause of weakening employee performance including lack of exemplary examples in leadership, seasonal work culture (a lot of work when at the end of the year), confused what to do, incomplete facilities, and less salary. The temporary conclusions that can be taken from the cause of the weakening of the work spirit in this institution are because of the work culture in this institution as well as insufficient compensation for employees.

Table. 1. Attendance of South Sipora Sub District Office Staff

\begin{tabular}{|c|c|c|c|}
\hline \multirow{3}{*}{ No } & \multicolumn{3}{|c|}{ Employee Attendance Frequency (\%) } \\
\cline { 2 - 4 } & 2015 & 2016 & 2017 \\
\cline { 2 - 4 } & $60 \%$ & $70 \%$ & $75 \%$ \\
\hline
\end{tabular}

\section{Literature Review}

\subsection{Organizational Culture}

Organizational culture is a pattern of shared assumptions as learning to overcome external problems and internal integration, taught to new members as the right way to understand, think and feel the problem. Robbins (2003) states that organizational culture is: "As a system of shared meanings adopted by members in an organization a decisive organization at a high level how employees act and distinguish these organizations from other organizations". The meaning system is a set of main characteristics that are valued by the organization. Every organization has a pattern of ritual beliefs, myths, and practices that have developed long ago. Riani (2011) states that: "Organizational culture is the subject of solving external and internal problems which are carried out consistently by a group which then bequeaths to new members as an appropriate way to understand, think and feel against related problems as above".

Riani (2011) suggests that there are ten characteristics of organizational culture as follows: group emphasis, people's focus, unit unification, control, risk tolerance, reward criteria, conflict tolerance, goal orientation, focus on open systems, and member identity. Kreiner and Kinicki (2005) suggest the function of organizational culture as follows: providing organizational identity to its employees; facilitate collective commitment; promote social system stability; and forming behavior by helping managers feel their existence. Tika (2008) divides organizational culture based on the information process as follows: rational culture, ideological culture, consensus culture, and hierarchical culture. Whereas if referred to Ndraha (2003) organizational culture is seen based on its objectives, namely: corporate organizational culture, culture of public organization, and culture of social organization.

\subsection{Compensation}

According to Kadarisman (2012) compensation is what employees or employees or workers receive in return for work given to companies or organizations. Handoko (2001) argues that compensation is something that employees receive as a reward for their work. According to Kadarisman (2012) there are five components in compensation, namely: wages, incentives, benefits, salaries, and pensions.

\subsection{Satisfaction}

According to Kreitner and Kinicki (2001), job satisfaction is "an effectiveness or emotional response to various aspects of work". Job satisfaction is seen as something relative, which is different from objective thinking and behavioral desires. Job satisfaction theory contains things that try to express things that make some people more satisfied with a job than some others. According to Samad (2006), job satisfaction can be divided into three types of variations, namely intrinsic, extrinsic, and general satisfaction. The following is an explanation of the three types of variations in job satisfaction: intrinsic satisfaction refers to employee performance, self-actualization, and a sense of accomplishment, such as freedom of work and task clarity, exstrinsic satisfaction is a form of appreciation given to employees, eneral Job Satisfaction is a collection a sense of job satisfaction for the various types of work that he has ever done. Mediani (2011) suggests job satisfaction through several aspects, including: salaries, promotions, superiors, multiple benefits, operational conditions of work, awards, coworkers, communication, and the work environment. 


\subsection{Performance}

Nitisemito (2002) formulates employee performance is the work that can be achieved by a person or group of people in an organization, in accordance with their respective authorities and responsibilities, in order to achieve the objectives of the organization legally, not violate the law and in accordance with the moral or ethics. According to Zainun (2001) there are several factors that influence employee performance: a harmonious relationship between leaders and subordinates, especially between work leaders who are directly connected and dealing with employees who are underneath, employee satisfaction towards those who are fully liked, usefulness to achieve organizational goals which are their shared goals must be realized together, only the level of economic satisfaction is adequate as a reward that is felt fair to the hard work that has been given to the organization, peace of mind, assurance and protection against anything that can endanger personal and career self in staffing.

According to Wursanto (2005) employees who have high performance in carrying out their duties can be known from several aspects, including: High discipline, Enthusiastic work, Harmonious relationships within the organization, High loyalty, Creativity and high initiative. According to Hasibuan (2006) indicators for measuring employee performance are: Job performance: Harmonious relationships in the organization, high creativity and initiative, work attendance and completion, responsibility, and personality. According to Mangkunegara (2007), there are 5 components to measure employee performance, namely: the ability to compile and realize work plans, implement instructions/orders from superiors, implement quality services to the community, work quality, and achieve work targets.

\section{Research Location}

Based on the titles raised, namely the effect of organizational culture and compensation on employee performance with satisfaction as an intervening variable in South Sipora Sub district, Mentawai Islands Regency. The study was conducted at the South Sipora Sub District Office in the Mentawai Islands Regency of West Sumatra Province implemented from September to November 2018.

\subsection{Conceptual Framework}

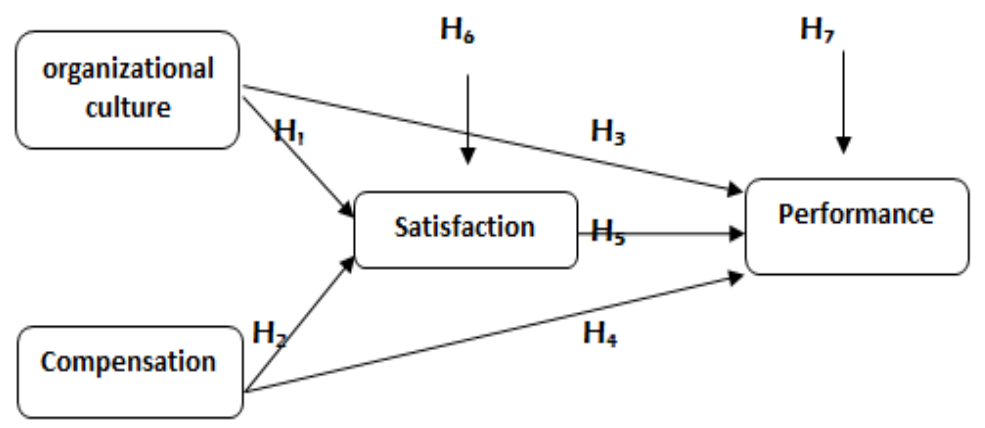

Figure 1. Conceptual Framework

Based on the conceptual framework, the hypothesis can be made as follows:

$\mathrm{H}_{1}$ : It is assumed that organizational culture has a positive and significant effect on employee satisfaction.

$\mathrm{H}_{2}$ : It is assumed that compensation has a positive and significant effect on employee satisfaction.

$\mathrm{H}_{3}$ : It is assumed that organizational culture has a positive and significant effect on employee performance.

$\mathrm{H}_{4}$ : It is assumed that compensation has a positive and significant effect on employee performance.

$\mathrm{H}_{5}$ : It is assumed that satisfaction has a positive and significant effect on employee performance.

$\mathrm{H}_{6}$ : It is assumed that organizational culture has a positive and significant effect through satisfaction with performance in the South Sipora Sub district Office, Mentawai Islands Regency.

$\mathrm{H}_{7}$ : It is assumed that compensation has a positive effect through satisfaction with employee performance in the South Sipora Sub district Office, Mentawai Islands Regency. 


\section{Methodology of research}

\subsection{Research Context}

This research takes the form of causality research with a quantitative approach. The design of causality research is a research that is structured to examine the possibility of a causal relationship between variables (Sanusi, 2014). This study begins with knowing the problem of the object of research to be examined, namely knowing whether there is a contribution of organizational culture and compensation to employee performance with satisfaction as an intervening variable. After the problem is known, a literature study and interview are conducted to look for theories that can be used as references to begin this research. Then proceed with making a research model using dependent variables. After the research model was created, the trial questionnaire was then continued to determine validity and reliability. If the validity is known, then a valid questionnaire is distributed to test the simulation and regression, path analysis.

\subsection{Measurement and Research Instruments}

The scale used in preparing the questionnaire is a Likert scale. Likert scale is used to measure attitudes, opinions and perceptions of a person or group of people about social phenomena (Sugiyono, 2015). With a Likert scale, the research variables to be measured and translated into variable indicators. Then the indicator is used as a starting point for compiling instrument items that can be in the form of statements. The Likert scale measurements in the study are as follows:

Table 2. Research Variable Measurement

\begin{tabular}{|c|l|c|c|}
\hline No & \multicolumn{1}{|c|}{ Answer Category } & Positive Score & Negative Score \\
\hline 1. & Strongly agree & 5 & 1 \\
\hline 2. & Agree & 4 & 2 \\
\hline 3. & Doubtful & 3 & 3 \\
\hline 4. & Disagree & 2 & 4 \\
\hline 5. & Strongly Disagree & 1 & 5 \\
\hline
\end{tabular}

\subsection{Data Collection and Samples}

Data collection techniques in this study were carried out using questionnaire distribution techniques. The respondents used were employees of the Sipora Selatan District Office, Mentawai Islands District, which numbered around 40 people. The sample used in this study is that all members of the population are used as samples. This is done because the population is less than 40 people. The sample in this study included male and female employees, a minimum work period of one year.

\section{Research Results}

The data analysis technique in this study uses quantitative analysis. This analysis technique is carried out on data obtained from the answers to questionnaires and is used to analyze data in the form of numbers and calculations using statistical methods. This study will use path analysis techniques with the help of SPSS. Path analysis is a statistical analysis technique which is a development of multiple regression analysis (Noor, 2011). To see the characteristics of respondents such as gender, age, education, occupation, length of work, and marital status, a descriptive analysis was conducted. Likewise, to look at research data from each variable (organizational culture variables, compensation, satisfaction, and performance) also carried out decryption analysis. Descriptive analysis was conducted to see the Total Respondent Achievement (TCR) of each indicator of each variable. Analysis of the description of the research data in the study was analyzed according to the Total Respondent Achievement (TCR) with the formula:

$\mathrm{TCR}=\mathrm{Rs} \times 100 \%$

$\mathrm{n}$

Where:

TCR: Total Respondent Achievement, Rs: Average respondent's answer score, n: Answer score value. 
Interpretation criteria for scores for Respondent Achievement Levels (TCR) are as follows:

Table 3. TCR Scala Range

\begin{tabular}{|c|c|c|}
\hline No & Number & Information \\
\hline 1. & $00 \%-20 \%$ & Very weak \\
\hline 2. & $21 \%-40 \%$ & Weak \\
\hline 3. & $41 \%-60 \%$ & Enough \\
\hline 4. & $61 \%-80 \%$ & Strong \\
\hline 5. & $81 \%-100 \%$ & Very strong \\
\hline
\end{tabular}

\subsection{Description of Research Data}

\section{Organizational culture}

Based on table 4 below, the Total Achievement of Respondents (TCR) items of organizational culture 1 amounted to $90.5 \%$, items of organizational culture 2 were $88.5 \%$, items of organizational culture 3 were $89 \%$, items of organizational culture 4 were $97 \%$ and items of organizational culture 5 were $91.5 \%$.

Table 4. Description of Organizational Culture Assessment Data

\begin{tabular}{|l|c|c|c|c|c|c|}
\hline \multicolumn{2}{|c|}{} & BOR1 & BOR2 & BOR3 & BOR4 & BOR5 \\
\hline \multirow{2}{*}{$\mathrm{N}$} & Valid & 40 & 40 & 40 & 40 & 40 \\
\cline { 2 - 7 } & Missing & 0 & 0 & 0 & 0 & 0 \\
\hline Mean & 4.5250 & 4.4250 & 4.4500 & 4.8500 & 4.5750 \\
\hline Std. Error of Mean & .07996 & .07916 & .08734 & .05718 & .07916 \\
\hline Median & 5.0000 & 4.0000 & 4.0000 & 5.0000 & 5.0000 \\
\hline Mode & 5.00 & 4.00 & 4.00 & 5.00 & 5.00 \\
\hline Std. Deviation & .50574 & .50064 & .55238 & .36162 & .50064 \\
\hline Variance & .256 & .251 & .305 & .131 & .251 \\
\hline Range & 1.00 & 1.00 & 2.00 & 1.00 & 1.00 \\
\hline Minimum & 4.00 & 4.00 & 3.00 & 4.00 & 4.00 \\
\hline Maximum & 5.00 & 5.00 & 5.00 & 5.00 & 5.00 \\
\hline Sum & 181.00 & 177.00 & 178.00 & 194.00 & 183.00 \\
\hline TCR & $\mathbf{9 0 , 5 \%}$ & $\mathbf{8 8 , 5 \%}$ & $\mathbf{8 9 \%}$ & $\mathbf{9 7 \%}$ & $\mathbf{9 1 , 5 \%}$ \\
\hline
\end{tabular}

\section{Compensation}

Based on table 4 above, the Total Achievement of Respondents (TCR) compensation items1 amounted to $87.5 \%$, compensation items 2 amounted to $91 \%$, compensation items 3 amounted to $88 \%$, compensation items 4 amounted to $91 \%$, compensation items 5 amounted to $90 \%$, and compensation items5 totaled $83.5 \%$.

Table 5. Description of Compensation Assessment Data

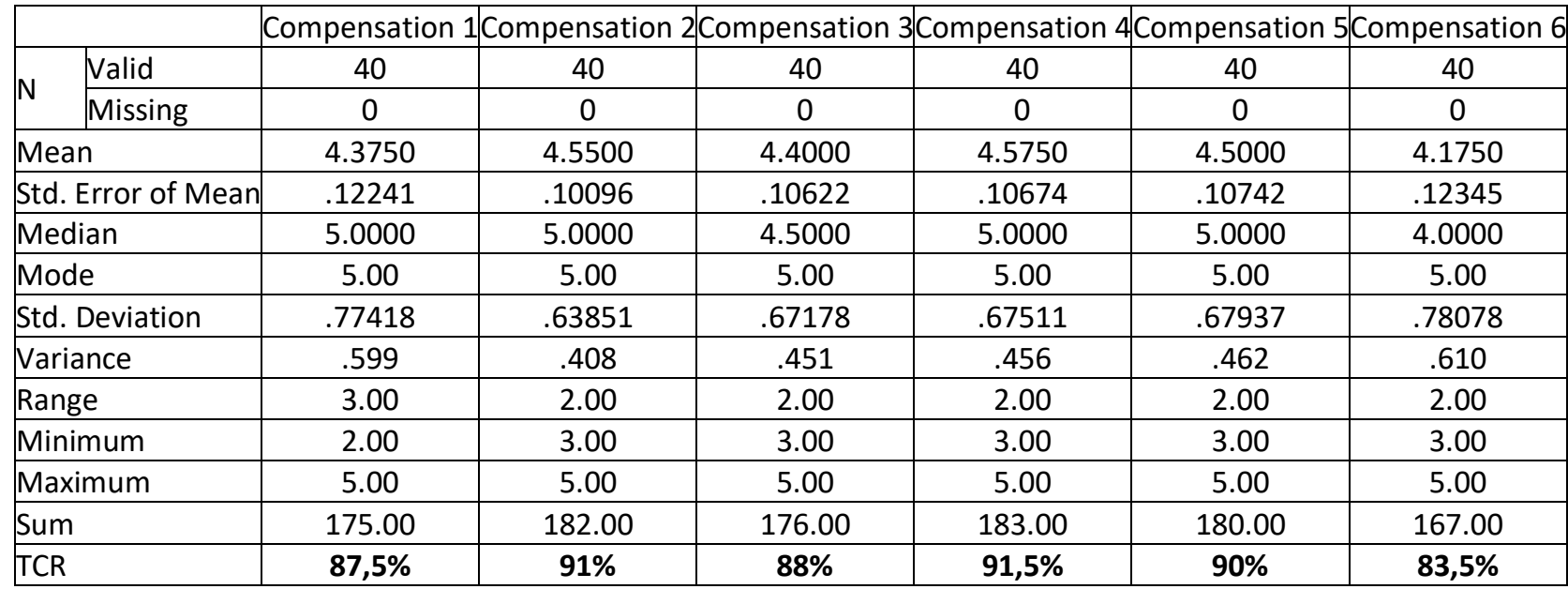




\section{Satisfaction}

Based on table 5 above, the total achievement of respondents (TCR) of satisfaction items1 amounted to $86.5 \%$, satisfaction items were $93.5 \%$, satisfaction items 3 were $91.5 \%$, compensation items 4 were $93 \%$, and compensation items 5 were $92,5 \%$.

Table 5. Description of Employee Satisfaction Assessment Data

\begin{tabular}{|c|c|c|c|c|c|c|}
\hline & \multicolumn{5}{|c|}{ Satisfaction 1 Satisfaction 2 Satisfaction 3Satisfaction 4Satisfaction 5} \\
\hline \multirow{2}{*}{ N } & Valid & 40 & 40 & 40 & 40 & 40 \\
\hline & Missing & 0 & 0 & 0 & 0 & $\mathrm{e} 0$ \\
\hline \multicolumn{2}{|c|}{ Mean } & 4.3000 & 4.6750 & 4.5750 & 4.6500 & 4.6000 \\
\hline \multicolumn{2}{|c|}{ Std. Error of Mean } & .12506 & .07500 & .10056 & .08435 & .09337 \\
\hline \multicolumn{2}{|c|}{ Median } & 4.5000 & 5.0000 & 5.0000 & 5.0000 & 5.0000 \\
\hline \multicolumn{2}{|c|}{ Mode } & 5.00 & 5.00 & 5.00 & 5.00 & 5.00 \\
\hline \multicolumn{2}{|c|}{ Std. Deviation } & .79097 & .47434 & .63599 & .53349 & .59052 \\
\hline \multicolumn{2}{|c|}{ Variance } & .626 & .225 & .404 & .285 & .349 \\
\hline \multicolumn{2}{|c|}{ Range } & 2.00 & 1.00 & 2.00 & 2.00 & 2.00 \\
\hline \multicolumn{2}{|c|}{ Minimum } & 3.00 & 4.00 & 3.00 & 3.00 & 3.00 \\
\hline \multicolumn{2}{|c|}{ Maximum } & 5.00 & 5.00 & 5.00 & 5.00 & 5.00 \\
\hline \multicolumn{2}{|c|}{ Sum } & 172.00 & 187.00 & 183.00 & 186.00 & 184.00 \\
\hline \multicolumn{2}{|c|}{ TCR } & $86 \%$ & $93,5 \%$ & $91,5 \%$ & $93 \%$ & $92 \%$ \\
\hline
\end{tabular}

\section{Employee Performance}

Based on table 6 above, the Total Achievement of Respondents (TCR) of performance items1 totaled $85.5 \%$, performance items 2 amounted to $90.5 \%$, performance items 3 totaled $91.5 \%$, performance items 4 totaled $91.5 \%$, and performance items 5 totaled $90 \%$.

Table 6. Description of Employee Performance Assessment Data

\begin{tabular}{|c|c|c|c|c|c|c|}
\hline & & \multicolumn{5}{|c|}{ Performance 1 Performance 2 Performance 3 Performance 4 Performance 5} \\
\hline & Valid & 40 & 40 & 40 & 40 & 40 \\
\hline $\mathrm{N}$ & Missing & 0 & 0 & 0 & 0 & 0 \\
\hline \multicolumn{2}{|c|}{ Mean } & 4.4750 & 4.5250 & 4.5750 & 4.5750 & 4.5250 \\
\hline \multicolumn{2}{|c|}{ Std. Error of Mean } & .08761 & .07996 & .09397 & .09397 & .08761 \\
\hline \multicolumn{2}{|c|}{ Median } & 4.5000 & 5.0000 & 5.0000 & 5.0000 & 5.0000 \\
\hline \multicolumn{2}{|c|}{ Mode } & 5.00 & 5.00 & 5.00 & 5.00 & 5.00 \\
\hline \multicolumn{2}{|c|}{ Std. Deviation } & 55412 & .50574 & .59431 & .59431 & .55412 \\
\hline \multicolumn{2}{|c|}{ Variance } & .307 & .256 & .353 & .353 & .307 \\
\hline \multicolumn{2}{|c|}{ Range } & 2.00 & 1.00 & 2.00 & 2.00 & 2.00 \\
\hline \multicolumn{2}{|c|}{ Minimum } & 3.00 & 4.00 & 3.00 & 3.00 & 3.00 \\
\hline \multicolumn{2}{|c|}{ Maximum } & 5.00 & 5.00 & 5.00 & 5.00 & 5.00 \\
\hline \multicolumn{2}{|c|}{ Sum } & 179.00 & 181.00 & 183.00 & 183.00 & 181.00 \\
\hline \multicolumn{2}{|c|}{ TCR } & $89,5 \%$ & $90,5 \%$ & $91,5 \%$ & $91,5 \%$ & $90 \%$ \\
\hline
\end{tabular}

\subsection{Normality test}

Based on the normal P-P graph the plot in the two equations shows that the data distribution follows the normal line (straight line). The same thing shown in table 7 of the Kolgomorov Smirnov test shows that the data is normally distributed, namely Asymp. Sig. greater than 0.05 , thus it can be concluded that the residual data is normally distributed and the regression model has met the assumptions of normality.

Table 7. Kolgomorov-Smirnov Test

\begin{tabular}{|l|c|c|}
\hline & $\begin{array}{c}\text { Unstandardized Residual } \\
\text { Equation 1 }\end{array}$ & $\begin{array}{c}\text { Unstandardized Residual } \\
\text { Equation 2 }\end{array}$ \\
\hline Asymp. Sig. (2-tailed) & 0,971 & 0,838 \\
\hline
\end{tabular}




\subsection{Homogeneity Test}

Based on table 8 , it is known that the significance value of the variable organizational culture, compensation and satisfaction is greater than $0.05(0.082>0.05),(0.624>0.05),(0.158>0.05)$, meaning that the data has variances that same or homogeneous.

Table 8. Homogeneity Test

\begin{tabular}{|l|c|c|c|c|}
\hline & Levene Statistic & df1 & df2 & Sig. \\
\hline ORGANIZATIONAL CULTURE & .765 & 5 & 34 & .082 \\
\hline COMPENSATION & .705 & 5 & 34 & .624 \\
\hline SATISFACTION & 1.713 & 5 & 34 & .158 \\
\hline
\end{tabular}

\subsection{Linearity Test}

Based on table 9 it is known that the significance value is small than 0.05 (sig $<0.05$ ), which means there is a linear relationship.

Table 9. Employee Satisfaction and Organizational Culture

\begin{tabular}{|l|c|}
\hline & Sig. \\
\hline Satisfaction*Organizational Culture $\quad$ Linearity & .002 \\
Satisfaction*Compensation & .000 \\
Performance* Organizational Culture & .004 \\
Performance* Compensation & .000 \\
Performance* Satisfaction & .001 \\
\hline
\end{tabular}

\subsection{Multicollinearity Test}

Based on table 10, it is known that the tolerance value of all independent variables is $>0.10$. The variance inflation factor (VIF) value of the three variables $<10$, based on the criteria in decision making, it can be concluded that there is no multicollinearity.

Table 10. Tolerance and VIF Multicollinearity Test

\begin{tabular}{|l|c|c|c|c|}
\hline \multirow{2}{*}{ Model } & Equation & 1 & \multicolumn{2}{c|}{ Equation } \\
\cline { 2 - 5 } & Tolerance & VIF & Tolerance & VIF \\
\hline Organizational Culture & 0,919 & 1,088 & 0,773 & 1,293 \\
Compensation & 0,919 & 1,088 & 0,673 & 1,487 \\
Satisfaction & & & 0,566 & 1,767 \\
\hline
\end{tabular}

\subsection{Effect of Organizational Culture and Compensation on Satisfaction}

$f t$ count $>t$-table, then $H_{o}$ is rejected and $H a$ is accepted and vice versa t-count $<t$-table, then $H_{o}$ is accepted and $\mathrm{Ha}$ is rejected. The number of $\mathrm{t}$-table with the provisions of $\alpha=0.05$ and $\mathrm{df}=(\mathrm{n}-\mathrm{k})$ or $(40-3)=$ 37. From the provisions obtained t-table of 1.68709 .

Table 11. Effect of Organizational Culture \& Compensation on Satisfaction

\begin{tabular}{|l|c|c|c|}
\hline \multirow{2}{*}{ Model } & Unstandardized Coefficients & \multirow{2}{*}{$\mathrm{t}$} & \multirow{2}{*}{ Sig. } \\
\cline { 2 - 2 } & Beta & & \\
\hline (Constant) & 6,290 & 1,771 & 0,085 \\
Organization Culture & 0,415 & 2,643 & 0,012 \\
Compensation & 0,265 & 3,683 & 0,001 \\
\hline
\end{tabular}

\section{Effect of Organizational Culture on Employee Satisfaction}

Based on the results of the calculation, obtained the t-count of $2.643>t$-table of 1.68709 , so Ho is rejected and $\mathrm{Ha}$ is accepted. This means that there is a contribution between organizational culture to employee satisfaction. The amount of contribution given by the variable organizational culture to employee satisfaction $=0.415$ or $41.5 \%$ is considered significant with a significance level of $0.012<\alpha=0.05$. 


\section{Effect of Compensation on Employee Satisfaction}

Based on the results of the calculation, obtained the t-count of 3.683>t-table of 1.68709 so that Ho is rejected and $\mathrm{Ha}$ is accepted. This means that there is an influence between compensation to employee satisfaction. The magnitude of the effect of compensation on employee satisfaction $=0.265$ or $26.5 \%$ is considered significant with a significance number of $0.001<\alpha=0.05$.

Table 12. Effect of Organizational Culture, Satisfaction and Compensation on Employee Performance partially

\begin{tabular}{|l|c|c|c|}
\hline \multirow{2}{*}{ Model } & Unstandardized Coefficients & \multirow{2}{*}{ S } & \multirow{2}{*}{ Sig. } \\
\cline { 2 - 2 } & Beta & & \\
\hline (Constant) & 9,292 & 0,027 \\
Organizational Culture & 0,105 & 0,562 & 0,578 \\
Satisfaction & 0,404 & 2,249 & 0,031 \\
Compensation & 0,067 & 0,728 & 0,471 \\
\hline
\end{tabular}

Source: Data processed

If $t$ count $>t$-table, then $H_{o}$ is rejected and $H_{a}$ is accepted and vice versa $t$-count $<t$-table, then $H o$ is accepted and $\mathrm{Ha}$ is rejected. The number of $\mathrm{t}$-table with the provisions of $\alpha=0.05$ and $\mathrm{dk}=(\mathrm{n}-\mathrm{k})$ or $(40-4)=$ 36. From the provisions obtained t-table number of 1.68830 .

\section{Discussions and Conclusions}

\section{Effect of Organizational Culture on Employee Satisfaction}

Based on the results of testing, it is known that organizational culture has a positive and significant effect on employee satisfaction, meaning that an increase in organizational culture will be followed by an increase in employee satisfaction.

\section{Effect of compensation on Employee Satisfaction}

Based on the results of testing, it is known that giving compensation has a positive and significant effect on employee satisfaction, meaning that increasing compensation for employees will be followed by an increase in employee satisfaction.

\section{Effect of Organizational Culture on Employee Performance}

Berdasarkan hasil pengujian, diketahui bahwa budaya organisasi yang ada di Kantor Kecamatan Sipora Selatan ternyata tidak berpengaruh terhadap kinerja pegawai, artinya meningkat atau menurunnya budaya organisasi tidak memiliki efek terhadap peningkatan atau penurunan semangat kerja pegawai. Based on the results of testing, it is known that the organizational culture in the South Sipora Sub district Office did not affect employee performance, meaning that the increase or decrease in organizational culture has no effect on the increase or decrease in employee morale.

\section{Effect of compensation on Employee Performance}

Based on the results of testing, it is known that giving compensation to employees in South Sipora Sub district does not affect the increase in employee performance, meaning that an increase or decrease in compensation does not make employee performance increase or decrease.

\section{Effect of Employee Satisfaction on Employee Performance}

Based on the test results, it is known that employee satisfaction has a positive and significant effect on employee performance, meaning that an increase in employee satisfaction will be followed by an increase in employee performance.

\section{Effect of organizational culture through satisfaction with employee performance}

Based on the results of the above calculation it is known that the direct effect value is 0.089 and the indirect effect is 0.142 which means the value of indirect influence is greater than the value of direct 
influence. These results indicate indirectly the organizational culture through satisfaction has an influence on employee performance.

\section{Effect of compensation through satisfaction with employee performance}

Based on the results of the calculation above it is known that the direct effect value is 0.124 and the indirect effect is 0.417 which means the value of indirect influence is greater than the value of direct influence. These results indicate indirectly compensation through satisfaction has an influence on employee performance.

\section{References} Indonesia

1. Alex., S, Nitisemito (2002). Manajemen Personalia. Cetakan ke 9. Edisi ke 4. Jakarta: Ghalia

2. Anwar, S. (2014). Metodologi Penelitian Bisnis. Jakarta: Salemba Empat

3. Buchari, Z. (2001). Manajemen Sumber Daya Manusia Indonesia. Jakarta: Gunung Agung.

4. Draha, T. (2003). Teori Budaya Organisasi. Jakarta : PT. Rineka Cipta.

5. Handoko, H. T. (2001). Manejemen Personalia \& Sumberdaya Manusia. Yogyakarta: BPFE

6. Hasibuan, M.S.P. (2006). Manajemen Dasar, Pengertian, dan. Masalah, Edisi Revisi. Jakarta: Bumi Aksara

7. Kadarisman (2012). Manajemen Kompensasi. Cetakan ke -1 Jakarta: PT. RajaGrafindo Persada.

8. Kreitner, R, \& Kinicky, A. (2001). Organizational Behaviour. New York:McGraw-Hill

9. Kreitner, R.t and Kinicki, A. (2005). Perilaku Organisasi . Jakarta: Salemba Empat

10. Mangkunegara, A.A., Prabu, A. (2007). Manajmen Sumber Daya Manusia. Cetakan ke-7. Bandung: PT. Remaja Rosdakarya.

11. Mediani, A.G. (2011). Komitmen Organisasi Karyawan PT. X Ditinjau dari Kepuasan terhadap Kompensasi. Skripsi (tidak Diterbitkan). Semarang: Universitas Katolik Soegijapranata.

12. Noor, J. (2011). Metode Penelitian: Skripsi, Tesis, Disertasi, dan Karya Ilmiah. Jakarta: Kencana Prenada Media Group.

13. Qolquitt, J. A. (2009). Organizational Behavior: Improving Performace and Commitment in The Wokplace. New York: McGraw-Hill.

14. Riani, A. L. (2011). Budaya Organisasi. Yogyakarta : Graha IImu.

15. Stephen P. R. (2003). Perilaku Organisasi. Jakarta: Gramedia.

16. Samad, S. (2006). Prediction Turnover Intenstions. The Case of Malaysian Government Doctors. The Journal of American Academic of Business, Cambridge, Vol 8, No. 2 March

17. Sugiyono (2014). Metode Penelitian Bisnis. Bandung: Alfabeta, CV, 2010, Metode Penelitian Pendidikan. Bandung: CV Alfabeta

18. Tika, P. M. (2008). Budaya Organisasi dan Peningkatan Kerja Perusahaan. Jakarta: Bumi Aksara Wursanto (2007). Dasar-Dasar Ilmu Organisasi. Yogyakarta: Liberty. 